\title{
Implementasi Data Mining Untuk Menentukan Pola Penyebab Kecelakaan Lalu Lintas Di Wilayah Kota Palembang Menggunakan Algoritma FP-Growth
}

\author{
Fathan Pangestu ${ }^{1}$, Andri*2 $^{* 2}$ \\ 1,2Information System Departement, Bina Darma University, Palembang, Indonesia \\ Email: fathanpangestu97@gmail.com ${ }^{1}$, andri@binadarma.ac.id ${ }^{2}$
}

\begin{abstract}
Palembang City is one of the big cities in Indonesia. Along with the increasing population and the increasing number of motorized vehicles, it will certainly have an impact on the increasing number of traffic accidents in the city of Palembang. In this study, the writer will determine the pattern of traffic accidents by using the fp-growth algorithm and using various variables. The variables that will be used consist of weather, time of incident, road geometry, profession, level of injury. This research is expected to be a reference for the police to be able to take anticipatory measures in order to reduce the number of traffic accidents in the Palembang City area. The fp-growth algorithm can be applied properly to determine the pattern of the causes of traffic accidents in the city of Palembang by using 2 minimum support of $40 \%$ and $50 \%$ and 2 minimum confidence of $70 \%$ and $90 \%$. Based on the resulting rules, there are rules with the highest confidence value of $98 \%$ with these rules: When an accident occurs with a Side-Side accident type, the accident occurs in sunny weather conditions.
\end{abstract}

Keywords: association rules, fp-growth, traffic accident, data mining

\section{PENDAHULUAN}

Indonesia merupakan negara dengan jumlah kecelakaan lalu lintas yang besar. Menurut data dari WHO (World Healthy Organization), Indonesia menempati urutan kelima dengan jumlah kematian yang disebabkan dari kecelakaan lalu lintas. Setidaknya terdapat 3 faktor utama penyebab dari kecelakaan lalu lintas yaitu faktor manusia, kendaraan, dan jalan. Sebagai salah satu Negara yang berkembang Indonesia mengalami permasalahan lalu lintas yang lebih kompleks dibandingkan dengan negara-negara maju, salah satunya ialah kecelakaan lalu lintas. Angka kecelakaan lalu lintas di Indonesia cenderung cukup tinggi bila dibandingkan dengan negara-negara yang ada di ASEAN. 


\section{Journal of Software Engineering Ampera}

Vol. 1, No. 2, June 2020 e-ISSN: 2775-2488

https://journal-computing.org/index.php/journal-sea/index

Kota Palembang merupakan salah satu kota besar yang berada di Indonesia. Seiring dengan meningkatnya jumlah penduduk dan meningkatnya jumlah kendaraan bermotor tentunya akan berdampak pada angka kecelakaan lalu lintas di wilayah Kota Palembang yang semakin tinggi. Menurut data dari Polrestabes Palembang angka kecelakaan lalu lintas di tahun 2017 telah terjadi sekitar 332 kejadian, di tahun 2018 mengalami kenaikan menjadi 360 kejadian, dan di bulan januari sampai maret 2019 telah terjadi 156 kejadian.

Berdasarkan permasalahan diatas, peneliti akan mencoba untuk menerapkan algoritma fp-growth untuk menentukan pola penyebab kecelakaan lalu lintas di wilayah Kota Palembang. Algoritma fp-growth merupakan salah satu alternatif algoritma yang dapat digunakan untuk menentukan himpunan data yang paling sering muncul dalam sekumpulan data. Karakteristik algoritma fp-growth adalah struktur data yang digunakan dalam tree yang disebut $f p$-tree. Dengan menggunakan $f p$-tree, algoritma fp-growth dapat langsung mengestrak frequent itemset dari fp-tree.

Pada penelitian ini penulis akan menentukan pola penyebab kecelakaan lalu lintas dengan menggunakan algoritma fp-growth dan menggunakan berbagai variabel. Variabel yang akan digunakan terdiri dari waktu kejadian, tipe kecelakaan, kendaraan yang terlibat, tingkat kecelakaan, cuaca, fungsi jalan, bentuk geometri jalan, kondisi permukaan jalan. Penelitian ini diharapkan dapat menjadi acuan kepolisian untuk dapat melakukan tindakan antisipasi agar terjadi penurunan angka kecelakaan lalu lintas di wilayah Kota Palembang.

\section{METODOLOGI PENELITIAN}

\subsection{Metode Analisis Data}

Tahapan menganalisis data dalam penerapan data mining ini menggunakan tahapan Knowledge Discovery in Database (KDD) yang terdiri dari beberapa tahapan [1] :

1) Data Selection (Seleksi Data) pada tahap ini yaitu melakukan penyeleksian atau pemilihan atribut-atribut data yang akan digunakan didalam tahap penerapan data mining.

2) Data Integration (Integrasi Data) adalah proses penggabungan data.

3) Data Cleaning (Pembersihan Data) sebelum proses data mining maka perlu melakukan proses cleaning atau pembersihan data dari data yang mengandung missing value dan data yang mengandung redundant. 
4) Data Transformation (Transformasi Data) adalah mengubah data menjadi data yang siap untuk digunakan dalam proses data mining.

5) Data Mining merupakan tahapan untuk menemukan pola informasi dari sekumpulan data dengan menggunakan teknik algoritma tertentu.

6) Pattern Evaluation (Evaluasi Pola) yaitu proses mengidentifikasi pola-pola yang menarik.

\subsection{Data Mining}

Data mining atau penambangan data tidaklah termasuk dalam bidang baru. Salah satu kesulitan dalam mendefinisikan data mining adalah fakta bahwa data mining atau penambangan data telah mewarisi banyak aspek dan teknologi dari bidang ilmiah yang telah mapan [2]. Berawal dari beberapa disiplin ilmu, data mining bertujuan untuk memperbaiki teknik tradisional sehingga bisa menangani:

a. Jumlah data yang sangat besar.

b. Dimensi data yang tinggi.

c. Data yang heterogen dan berbeda sifat.

Pendapat lain mengatakan Data mining atau penambangan data adalah sebuah teknik yang mempunyai kegunaan yaitu teknik statistik, matematika, kecerdasan buatan dan pembelajaran mesin untuk mengekstrak dan identifikasi berbagai informasi berguna dan pengetahuan terkait database besar [3].

\subsection{Association Rules}

Association rules atau aturan asosiasi adalah teknik penambangan data yang digunakan temukan aturan asosiasi antara kombinasi suatu item. Analisis asosiasi juga dikenal sebagai dasar dari teknologi data mining, itu adalah dasar dari teknologi data mining lain. Terutama salah satu tahapan analisis korelasi telah menarik perhatian luas peneliti telah menghasilkan algoritma yang efektif, yaitu analisis mode frekuensi tinggi. Teknik ini memiliki 2 langkah. Langkah pertama adalah lakukan kalkulasi untuk menemukan frequent itemsets, langkah kedua adalah menemukan aturan asosiasi sekumpulan item yang sering (aturan) [4]. Dalam teknik association rules terdapat 2 kriteria yaitu nilai support dan nilai confidence. Nilai support untuk aturan asosiasi adalah untuk menyajikan kombinasi dari item ini dalam database, jika Anda memiliki item $A$ dan item B, nilai support adalah rasio dalam transaksi 


\title{
Journal of Software Engineering Ampera
}

Vol. 1, No. 2, June 2020 e-ISSN: 2775-2488

https://journal-computing.org/index.php/journal-sea/index

database berisi A dan B. Rumus untuk menghitung nilai support dua item ini adalah sebagai berikut:

\author{
Support $(A)=\sum$ Transaksi Mengandung $A$ \\ $\sum$ Transaksi \\ Support $(A, B)=\sum$ Transaksi Mengandung A dan B \\ $\sum$ Transaksi
}

Nilai confidence aturan asosiasi adalah ukuran akurasi aturan (yaitu, representasi) transaksi dalam database yang mengandung nilai A dan B kita dapat mengukur kekuatan hubungan antar item dalam aturan asosiasi. rumus hitung nilai kepercayaan dari kedua item tersebut sebagai berikut:

\section{Confidence $=\mathrm{P}(\mathrm{A} \backslash \mathrm{B})=\sum$ Transaksi Mengandung $\mathrm{A}$ dan $\mathrm{B}$ $\sum$ Transaksi Mengandung A}

\subsection{Fp-Growth}

Fp-growth adalah algoritma alternatif dapat digunakan untuk menentukan item yang paling sering muncul dalam himpunan data. Fp-growth digunakan dengan ontoh yang digunakan dalam algoritma apriori [5]. FP-Growth menggunakan konsep membangun pohon saat mencari frequent itemsets. Inilah alasan mengapa algoritma fp-growth lebih cepat daripada algoritma apriori. Ciri dari algoritma fp-growth adalah struktur data yang digunakan adalah pohon yang disebut dengan $f p$-tree. Dengan menggunakan $f p$-tree, algoritma fp-growth dapat langsung diekstraksi kumpulan item yang sering muncul di $f p$-tree. Fp-Growth adalah struktur penyimpanan data kompresi. Membangun $f p$-tree dengan memetakan setiap data transaksi ke setiap pohon transaksi jalur yang ditentukan di fp-tree. Karena dalam setiap transaksi yang dipetakan, transaksi dengan item yang sama, maka jalur antara satu sama lain dimungkinkan datang. Lebih banyak data transaksi dengan item yang sama, proses kompresi menggunakan struktur data fp-tree menjadi semakin efektif [2]. Menggunakan algoritma FP-Growth untuk menambang itemsets yang akan digunakan untuk menghasilkan struktur pohon data (FP-Tree). Metode FP-Growth dapat dibagi menjadi 3 tahapan utama yaitu sebagai berikut :

a. Tahap pembangkitan conditional pattern base

b. Tahap pembangkitan conditional fp-tree

c. Tahap pencarian frequent itemset 


\section{Journal of Software Engineering Ampera}

Vol. 1, No. 2, June 2020 e-ISSN: 2775-2488

https://journal-computing.org/index.php/journal-sea/index

\subsection{Rapidminer}

Rapidminer adalah software untuk mengolah data dengan menggunakan prinsip dan algoritma data mining, rapidminer mengekstrak pola dari data melalui kumpulan besar metode statistik, kecerdasan buatan, dan database. RapidMiner memudahkan pengguna untuk menggunakannya saat menggunakan operator untuk menghitung data dalam jumlah besar. Operator ini digunakan untuk mengubah data. Data dihubungkan melalui node pada operator, maka kita hanya perlu menghubungkannya ke node hasil untuk melihat hasil. Hasil yang ditampilkan oleh rapidminer juga dapat ditampilkan secara visual dengan grafik. Rapidminer adalah salah satu opsi perangkat lunak untuk ekstraksi menggunakan metode penambangan data atau data mining [6].

\section{RESULTS AND DISCUSSION}

\subsection{Tahapan associaton rules dengan rapidminer}

Berikut ini merupakan proses association rules dengan menggunakan aplikasi rapidminer:

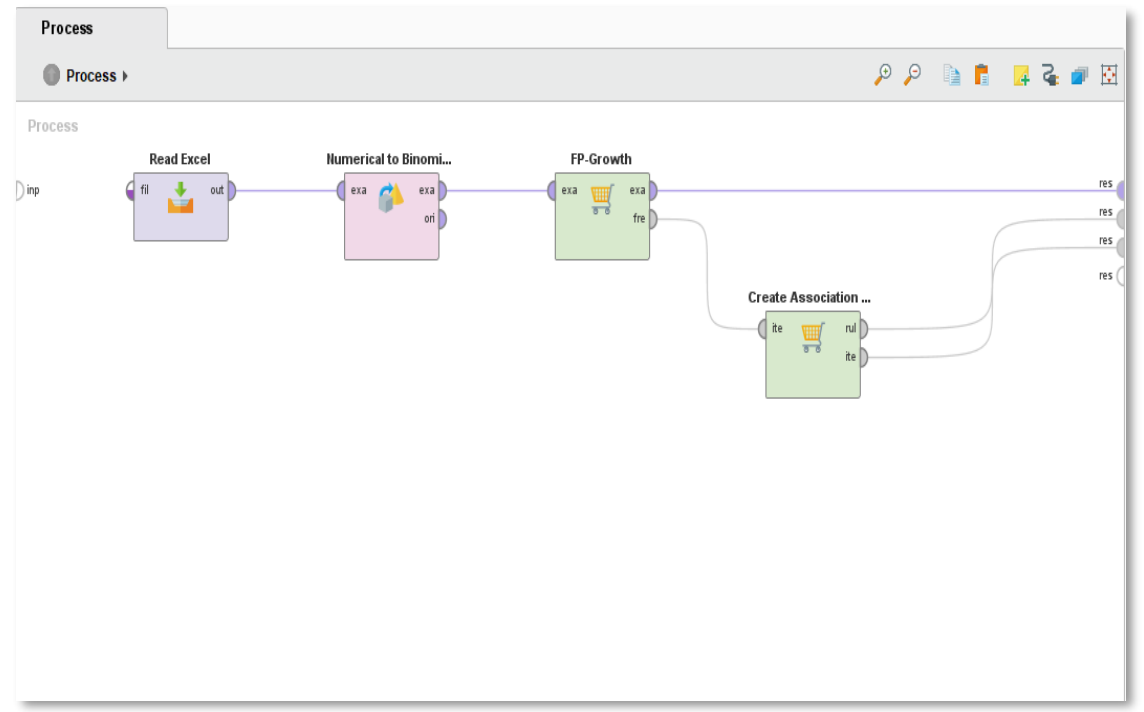

Gambar 1. Proses association rules menggunakan rapidminer 


\section{Journal of Software Engineering Ampera}

Vol. 1, No. 2, June 2020 e-ISSN: 2775-2488

https://journal-computing.org/index.php/journal-sea/index

Pada proses association rules berdasarkan data kecelakaan lalu lintas tahun 2017-2019 terdapat 4 operator, adapun operator tersebut sebagai berikut :

1) Read Excel

2) Numerical to Binominal

3) Fp-Growth

4) Create Association Rules

\subsection{Proses association rules dengan minimum support $40 \%$ dan minimum confidence $70 \%$}

Setelah semua tahapan operator untuk mencari association rules dijalankan dengan menggunakan minimum support sebesar $40 \%$ dan minimum confidence sebesar 70\%, maka akan mendapat hasil dari association rules berdasarkan data kecelakaan lalu lintas tahun 2017-2019. Berikut ini adalah gambar dari hasil association rules dengan minimum support sebesar $40 \%$ dan minimum confidence sebesar $70 \%$.

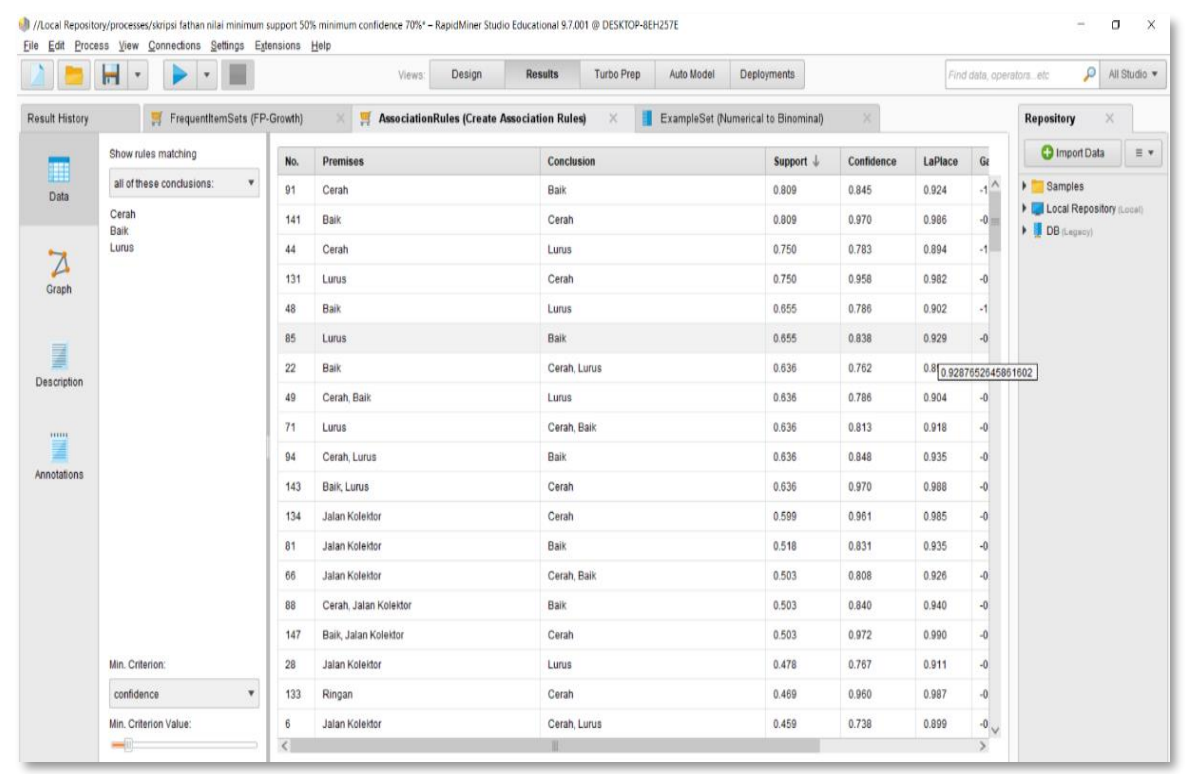

Gambar 2. Hasil association rules dengan minimum support $40 \%$

Berdasarkan hasil pada gambar diatas, maka didapatkan hasil rules dengan menggunakan minimum support sebesar $40 \%$ dan minimum confidence sebesar $70 \%$ berjumlah 24 rules. Berikut ini merupakan deskripsi dari hasil rules tersebut, yaitu: 
1) Rules 1 : Ketika terjadi kecelakaan di kondisi cuaca Cerah maka kecelakaan terjadi di kondisi permukaan jalan yang Baik.

2) Rules 2 : Ketika terjadi kecelakaan di kondisi permukaan jalan Baik maka kecelakaan terjadi di kondisi cuaca Cerah.

3) Rules 3 : Ketika terjadi kecelakaan di kondisi cuaca Cerahmaka kecelakaan terjadi di geometri jalan Lurus.

4) Rules 4 : Ketika terjadi kecelakaan di geometri jalan Lurus maka kecelakaan terjadi di kondisi cuaca Cerah.

5) Rules 5 : Ketika terjadi kecelakaan di kondisi permukaan jalan Baik maka kecelakaan terjadi di geometri jalan Lurus.

6) Rules 6 : Ketika terjadi kecelakaan di geometri jalan Lurus maka kecelakaan terjadi di kondisi permukaan jalan Baik.

7) Rules 7 : Ketika terjadi kecelakaan di kondisi permukaan jalan baik maka kecelakaan terjadi di kondisi cuaca Cerah dan permukaan jalan Baik.

8) Rules 8 : Ketika terjadi kecelakaan di kondisi cuaca Cerah dan permukaan jalan Baik maka kecelakaan terjadi di geometri jalan Lurus.

9) Rules 9 : Ketika terjadi kecelakaan di geometri jalan Lurus maka kecelakaan terjadi di kondisi cuaca Cerah dan permukaan jalan Baik.

10) Rules 10 : Ketika terjadi kecelakaan di kondisi cuaca Cerah dan geometri jalan Lurus maka kecelakaan terjadi di permukaan jalan Baik.

11) Rules 11 : Ketika terjadi kecelakaan di kondisi permukaan jalan Baik dan geometri jalan Lurus maka kecelakaan terjadi di kondisi cuaca Cerah.

12) Rules 12 : Ketika terjadi kecelakaan di fungsi Jalan Kolektor maka kecelakan terjadi di kondisi cuaca Cerah.

13) Rules 13 : Ketika terjadi kecelakaan di fungsi Jalan Kolektor maka kecelakaan terjadi di permukaan jalan Baik.

14) Rules 14 : Ketika terjadi kecelakaan di fungsi Jalan Kolektor maka kecelakaan terjadi di kondisi cuaca Cerah dan permukaan jalan Baik.

15) Rules 15 : Ketika kecelakaan terjadi di kondisi cuaca Cerah dan fungsi Jalan Kolektor maka kecelakaan terjadi di permukaan jalan Baik.

16) Rules 16 : Ketika terjadi kecelakaan di permukaan jalan Baik dan fungsi Jalan Kolektor maka kecelakaan terjadi di kondisi cuaca Cerah.

17) Rules 17 : Ketika terjadi kecelakaan di fungsi Jalan Kolektor maka kecelakaan terjadi di geometri jalan Lurus.

18) Rules 18 : Ketika terjadi kecelakaan dengan tingkat kecelakaan Ringan maka kecelakaan terjadi di kondisi cuaca Cerah.

19) Rules 19 : Ketika kecelakaan terjadi di fungsi Jalan Kolektor maka kecelakaan terjadi di kondisi cuaca Cerah dan geometri jalan Lurus. 


\section{Journal of Software Engineering Ampera}

Vol. 1, No. 2, June 2020 e-ISSN: 2775-2488

https://journal-computing.org/index.php/journal-sea/index

20) Rules 20 : Ketika kecelakaan terjadi di kondisi cuaca Cerah dan fungsi Jalan Kolektor maka kecelakaan terjadi di geometri jalan Lurus.

21) Rules 21 : Ketika kecelakaan terjadi di geometri jalan Lurus dan fungsi Jalan Kolektor maka kecelakaan terjadi di kondisi cuaca Cerah.

22) Rules 22 : Ketika kecelakaan terjadi dengan tipe kecelakaan Samping Samping maka kecelakaan terjadi di kondisi cuaca Cerah.

23) Rules 23 : Ketika kecelakaan terjadi dengan melibatkan kendaraan R2 X R2 maka kecelakaan terjadi di kondisi cuaca Cerah.

24) Rules 24 : Ketika kecelakaan terjadi dengan tingkat kecelakaan Ringan maka kecelakaan terjadi di permukaan jalan Baik.

\subsection{Proses association rule dengan minimum support $50 \%$ dan minimum confidence $70 \%$}

Pada proses association rules dengan minimum support $50 \%$ sama halnya dengan proses pada minimum support 40\%, yang membedakan hanya pada aturan minimum support pada operator fp-growth. Berikut ini adalah gambar dari hasil association rules dengan minimum support sebesar $50 \%$ dan minimum confidence sebesar $70 \%$ :

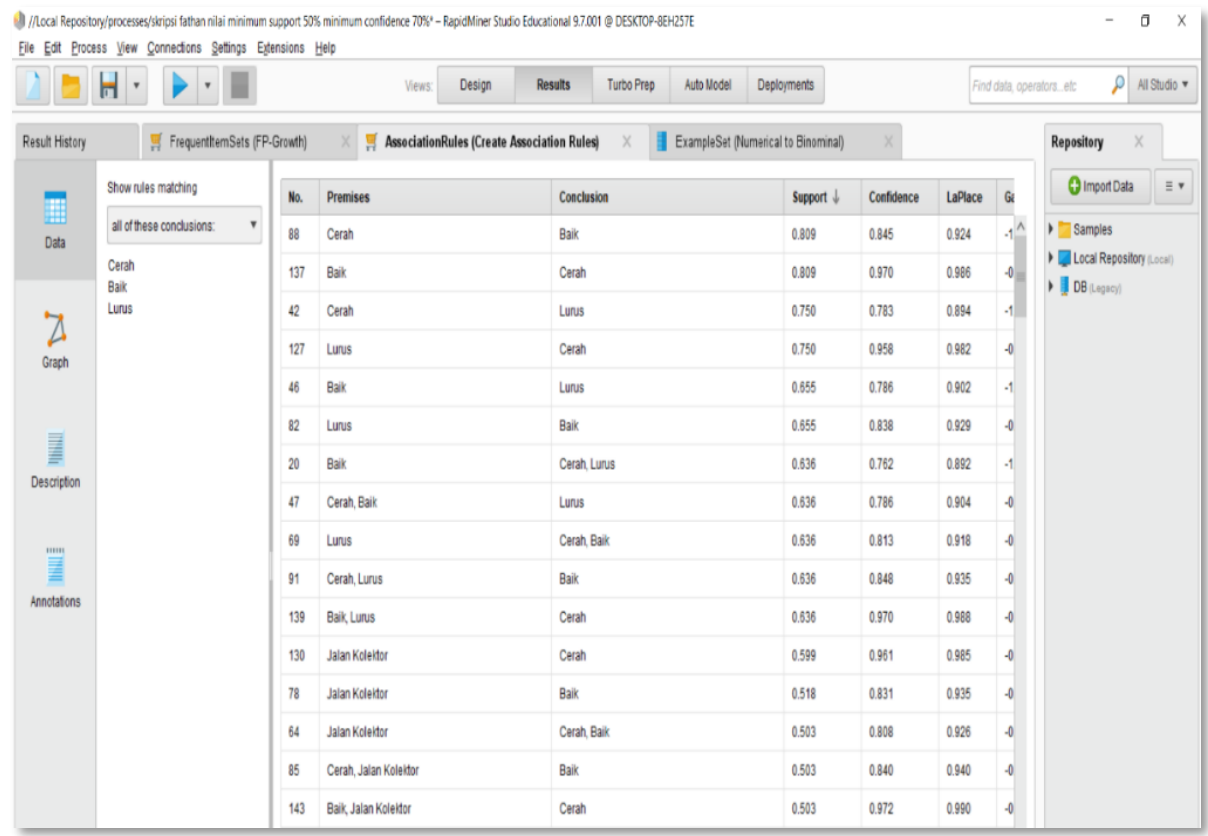

Gambar 3. Hasil association rules dengan minimum support $50 \%$ 
Berdasarkan hasil pada gambar diatas, maka didapatkan hasil rules dengan menggunakan minimum support sebesar 50\% dan minimum confidence sebesar 70\% berjumlah 16 rules. Berikut ini merupakan deskripsi dari hasil rules tersebut, yaitu:

1) Rules 1 : Ketika terjadi kecelakaan di kondisi cuaca Cerah maka kecelakaan terjadi di kondisi permukaan jalan yang Baik.

2) Rules 2 : Ketika terjadi kecelakaan di kondisi permukaan jalan Baik maka kecelakaan terjadi di kondisi cuaca Cerah.

3) Rules 3 : Ketika terjadi kecelakaan di kondisi cuaca Cerahmaka kecelakaan terjadi di geometri jalan Lurus.

4) Rules 4 : Ketika terjadi kecelakaan di geometri jalan Lurus maka kecelakaan terjadi di kondisi cuaca Cerah.

5) Rules 5 : Ketika terjadi kecelakaan di kondisi permukaan jalan Baik maka kecelakaan terjadi di geometri jalan Lurus.

6) Rules 6 : Ketika terjadi kecelakaan di geometri jalan Lurus maka kecelakaan terjadi di kondisi permukaan jalan Baik.

7) Rules 7 : Ketika terjadi kecelakaan di kondisi permukaan jalan baik maka kecelakaan terjadi di kondisi cuaca Cerah dan permukaan jalan Baik.

8) Rules 8 : Ketika terjadi kecelakaan di kondisi cuaca Cerah dan permukaan jalan Baik maka kecelakaan terjadi di geometri jalan Lurus.

9) Rules 9 : Ketika terjadi kecelakaan di geometri jalan Lurus maka kecelakaan terjadi di kondisi cuaca Cerah dan permukaan jalan Baik.

10) Rules 10 : Ketika terjadi kecelakaan di kondisi cuaca Cerah dan geometri jalan Lurus maka kecelakaan terjadi di permukaan jalan Baik.

11) Rules 11 : Ketika terjadi kecelakaan di kondisi permukaan jalan Baik dan geometri jalan Lurus maka kecelakaan terjadi di kondisi cuaca Cerah.

12) Rules 12 : Ketika terjadi kecelakaan di fungsi Jalan Kolektor maka kecelakan terjadi di kondisi cuaca Cerah.

13) Rules 13 : Ketika terjadi kecelakaan di fungsi Jalan Kolektor maka kecelakaan terjadi di permukaan jalan Baik.

14) Rules 14 : Ketika terjadi kecelakaan di fungsi Jalan Kolektor maka kecelakaan terjadi di kondisi cuaca Cerah dan permukaan jalan Baik.

15) Rules 15 : Ketika kecelakaan terjadi di kondisi cuaca Cerah dan fungsi Jalan Kolektor maka kecelakaan terjadi di permukaan jalan Baik.

16) Rules 16 : Ketika terjadi kecelakaan di permukaan jalan Baik dan fungsi Jalan Kolektor maka kecelakaan terjadi di kondisi cuaca Cerah

\subsection{Proses association rules dengan minimum support $40 \%$ dan minimum confidence $90 \%$}




\section{Journal of Software Engineering Ampera}

Vol. 1, No. 2, June 2020 e-ISSN: 2775-2488

https://journal-computing.org/index.php/journal-sea/index

Selanjutnya tahapan operator association rules dijalankan dengan menggunakan minimum support $40 \%$ dan menaikkan nilai confidence menjadi sebesar $90 \%$. Berikut ini adalah gambar dari hasil association rules dengan minimum support $40 \%$ minimum confidence sebesar $90 \%$ :

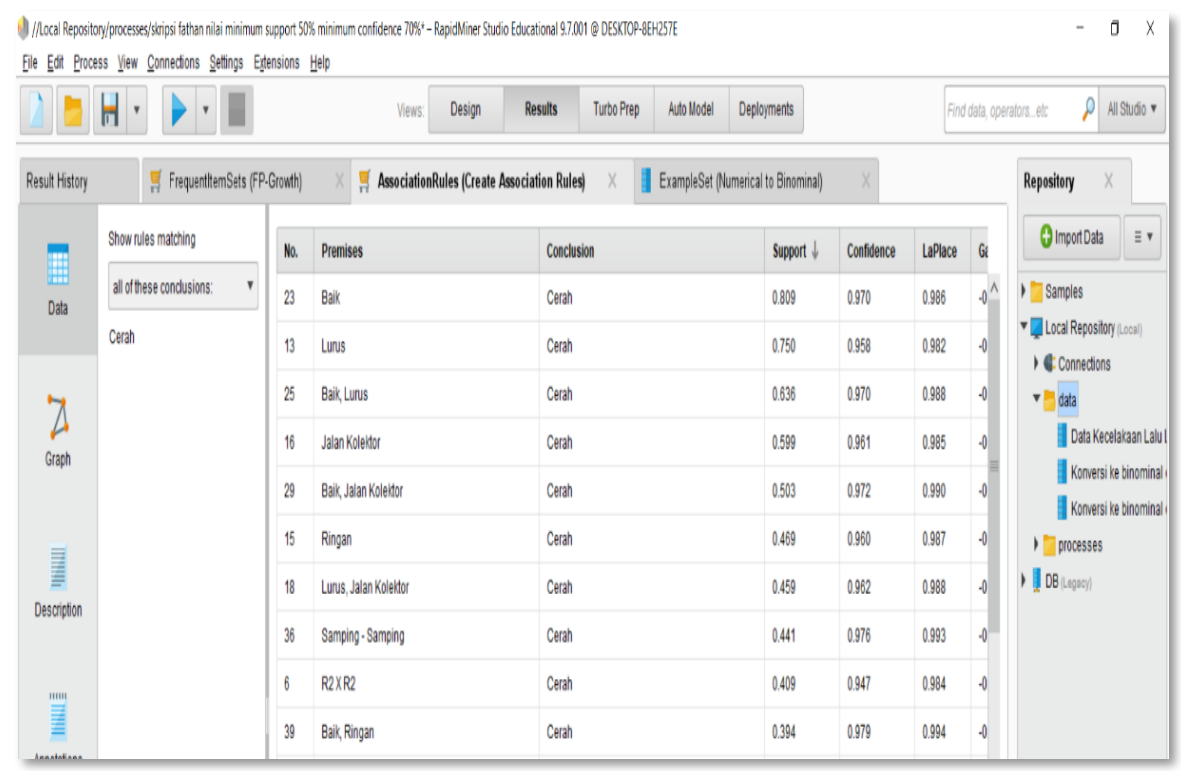

Gambar 4. Hasil association rules dengan minimum support $40 \%$ dan minimum confidence $90 \%$

Berdasarkan hasil pada gambar diatas, maka didapatkan hasil rules dengan menggunakan minimum support sebesar $40 \%$ dan minimum confidence sebesar $90 \%$ berjumlah 9 rules. Berikut ini merupakan deskripsi dari hasil rules tersebut, yaitu:

1) Rules 1 : Ketika kecelakan terjadi di kondisi permukaan jalan Baik maka kecelakaan terjadi di kondisi cuaca Cerah.

2) Rules 2 : Ketika kecelakaan terjadi di geometri jalan lurus maka kecelakaan terjadi di kondisi cuaca Cerah.

3) Rules 3 : Ketika kecelakaan terjadi di permukaan jalan baik dan geometri jalan lurus maka kecelakaan terjadi di kondisi cuaca Cerah.

4) Rules 4 : Ketika kecelakaan terjadi di fungsi Jalan Kolektor maka kecelakaan terjadi di kondisi cuaca Cerah.

5) Rules 5 : Ketika kecelakaan terjadi di permukaan jalan Baik dan fungsi Jalan Kolektor maka kecelakaan terjadi di kondisi cuaca Cerah. 


\section{Journal of Software Engineering Ampera}

Vol. 1, No. 2, June 2020 e-ISSN: 2775-2488

https://journal-computing.org/index.php/journal-sea/index

6) Rules 6 : Ketika kecelakaan terjadi dengan tingkat kecelakaan Ringan maka kecelakaan terjadi di kondisi Cuaca Cerah.

7) Rules 7 : Ketika kecelakan terjadi di geometri jalan Lurus dan fungsi Jalan Kolektor maka kecelakaan terjadi di kondisi cuaca Cerah.

8) Rules 8 : Ketika kecelakaan terjadi dengan tipe kecelakaan Samping Samping maka kecelakaan terjadi di kondisi cuaca Cerah.

9) Rules 9 : Ketika kecelakaan terjadi dengan melibatkan kendaraan R2 X R2 maka kecelakaan terjadi di kondisi cuaca Cerah.

\subsection{Proses association rules dengan minimum support $50 \%$ dan minimum confidence $90 \%$}

Pada langkah terkahir akan dilakukan proses association rules dengan menggunakan aturan minimum support sebesar $50 \%$ dan minimum confidence sebesar $90 \%$. Berikut ini adalah gambar hasil dari association rules dengan minimum support $50 \%$ dan minimum confidence $90 \%$ :

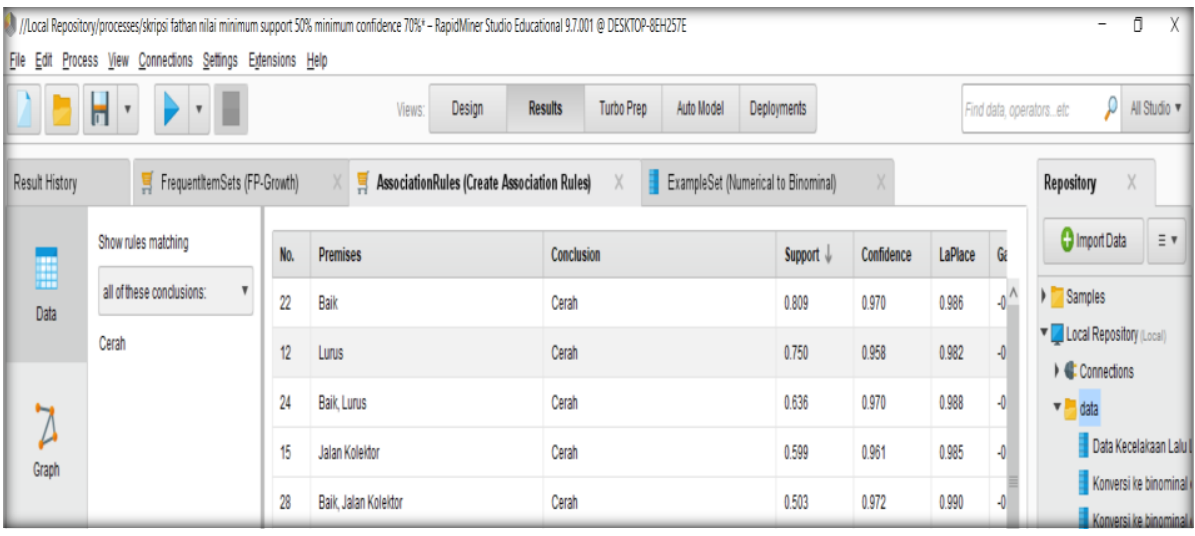

Gambar 5. Hasil association rules dengan minimum support $50 \%$ dan minimum confidence $90 \%$

Berdasarkan hasil pada gambar diatas, maka didapatkan hasil rules dengan menggunakan minimum support sebesar 50\% dan minimum confidence sebesar $90 \%$ berjumlah 5 rules. Berikut ini merupakan deskripsi dari hasil rules tersebut, yaitu :

1) Rules 1 : Ketika kecelakan terjadi di kondisi permukaan jalan Baik maka kecelakaan terjadi di kondisi cuaca Cerah.

2) Rules 2 : Ketika kecelakaan terjadi di geometri jalan Lurus maka kecelakaan terjadi di kondisi cuaca Cerah. 


\section{Journal of Software Engineering Ampera}

Vol. 1, No. 2, June 2020 e-ISSN: 2775-2488

https://journal-computing.org/index.php/journal-sea/index

3) Rules 3 : Ketika kecelakaan terjadi di permukaan jalan Baik dan geometri jalan Lurus maka kecelakaan terjadi di kondisi cuaca Cerah.

4) Rules 4 : Ketika kecelakaan terjadi di fungsi Jalan Kolektor maka kecelakaan terjadi di kondisi cuaca Cerah.

5) Rules 5 : Ketika kecelakaan terjadi di permukaan jalan Baik dan fungsi Jalan Kolektor maka kecelakaan terjadi di kondisi cuaca Cerah

\section{KESIMPULAN}

Dari hasil penelitian yang dilakukan, maka didapatkan kesimpulan sebagai berikut:

1) Algoritma fp-growth dapat diterapkan dengan baik untuk menentukan pola penyebab kecelakaan lalu lintas di wilayah kota Palembang dengan menggunakan 2 minimum support sebesar 40\% dan 50\% serta 2 minimum confidence sebesar $70 \%$ dan $90 \%$.

2) Berdasarkan minimum support $40 \%$ dan minimum confidence $70 \%$ didapatkan rules yang berjumlah 24 rules. Dengan nilai minimum support $50 \%$ dan minimum confidence $70 \%$ didapatkan rules berjumlah 16 rules. Dengan nilai minimum support 40\% dan minimum confidence $90 \%$ didapatkan rules berjumlah 9 rules. Dengan nilai minimum support 50\% dan minimum confidence $90 \%$ didapatkan rules berjumlah 5 rules.

3) Berdasarkan rules yang dihasilkan didapatkan rules dengan nilai confidence tertinggi sebesar $98 \%$ dengan rules : Ketika kecelakaan terjadi dengan tipe kecelakaan Samping - Samping maka kecelakaan terjadi di kondisi cuaca Cerah.

\section{DAFTAR PUSTAKA}

[1] A. Wijaya, 'Perbandingan Algoritma Eclat Dan Fp-Growth Pada Penjualan Barang (Studi Kasus: Minimarket 212 Mart Veteran Utama)', p. 10, 2019.

[2] A. Maulana and A. A. Fajrin, 'Penerapan Data Mining Untuk Analisis Pola Pembelian Konsumen Dengan Algoritma Fp-Growth Pada Data Transaksi Penjualan Spare Part Motor', klik, vol. 5, no. 1, p. 27, Feb. 2018, doi: 10.20527/klik.v5i1.100.

[3] M. Ridwan and H. Suyono, 'Penerapan Data Mining Untuk Evaluasi Kinerja Akademik Mahasiswa Menggunakan Algoritma Naive Bayes Classifier', vol. 7, no. 1, p. 6, 2013.

[4] B. A. Tama, 'Penetapan Strategi Penjualan Menggunakan Association Rules dalam Konteks CRM', vol. 5, p. 4, 2010. 
[5] G. Gunadi and D. I. Sensuse, 'penerapan metode data mining market basket analysis terhadap data penjualan produk buku dengan menggunakan algoritma apriori dan frequent pattern growth (fpgrowth) : studi kasus percetakan pt. Gramedia', p. 15, 2012.

[6] Brilian Rahmat C.T.I. et al., 'Implemetasi K-Means Clustering Pada Rapidminer Untuk Analisis Daerah Rawan Kecelakaan', p. 5, 2017. 